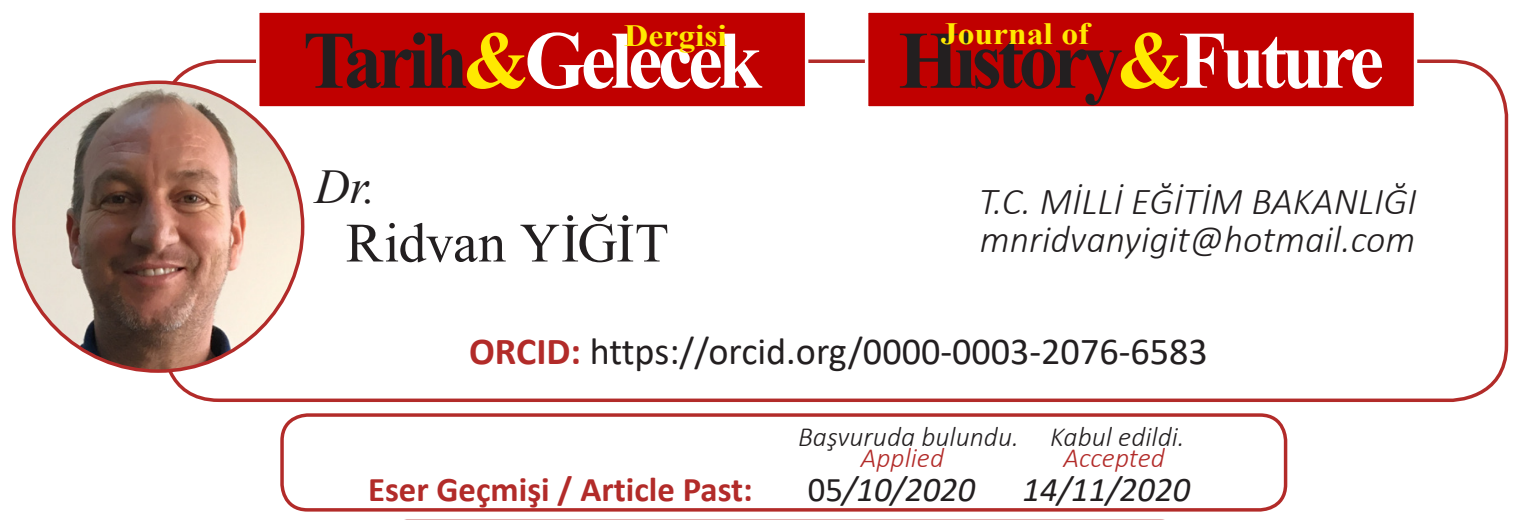

Araştırma Makalesi

DOI: http://dx.doi.org/10.21551/jhf.805924

Research Paper

Orjinal Makale / Orginal Paper

\title{
Muhammed b. Kalavun Dönemi'nde (1285-1341-H. 684-741) Ehl-i Zimmet ve Hıristiyan Dünya ile İlişkiler Hakkında Bir Değerlendirme
}

\author{
An Assessment of Relations with Non-Muslims and Christian World During \\ Muhammed b. Kalavun Era (1285-1341-H. 684-741)
}

\section{$\ddot{O} \mathbf{z}$}

Yakındoğu coğrafyasında 267 yıl hüküm süren Memlûklar(1250-1517), devletin kuruluş, örgütleniş ve işleyiş̧i bakımından Mısır ve bölge tarihinin önemli devletlerindendir. Muhammed b. Kalavun da (1293-1341) Memlûk tarihinde devleti en uzun süre yöneten hükümdar olmasının yanı sıra çağdaşı olan Hıristiyan devletler ve ehl-i zimmet ile ilişkileri bakımından dikkate değer sultanlarından biridir.

$\mathrm{Bu}$ çalışmada Muhammed b. Kalavun Dönemi sosyo-kültürel ve siyasi tarihinin şekillenmesine etki eden din faktörü incelenmeye çalışılmıştır. Sultan Baybars'ın hilafeti himaye politikasıyla kendine İslâm dünyasının hâmisi rolünü de yükleyen bir devlet olarak Memlûklarda kuşkusuz dâhilî ve haricî siyasette dinin rolü büyüktü. İncelemeye konu olan dönem, Memlûk tarihinde siyasî nüfuz, iktisadî başarı ve bazı istisnaî olaylar hariçte tutulacak olursa toplumu oluşturan sosyal yapıdaki dengeli siyaset bakımlarından müstesna bir mevki işgal etmektedir.

Memlûk Devleti kurulduğu sıralarda Haçlı Seferleri etkisini yitirmiş ve seferler sırasında elde edilen kazanımlar korunmaya çalış1lyyor olsa da fikrî açıdan haçlı düşüncesinin tamamen ortadan kalkmadığ 1 söylenebilir. Hıristiyanlı̆̆ın yayılma sürecinde Roma ile beraber hayatî rol oynayan üç merkezden ikisinin -İskenderiye ve Antakya Piskoposluklar1- Memlûk hâkimiyetinde olması bu devleti Hıristiyanlar gözünde de önemli kılmaktaydı. Çalışmanın amacı, devletin kuruluş dönemlerinde temelleri atılan ve politik bir motivasyon kaynağı olarak görülen dinin Muhammed $b$. Kalavun Dönemi'nde devlet politikalarına etkisini ortaya koymaktır.

Anahtar Kelimeler: Memlûklar, Muhammed b. Kalavun, Din, Hıristiyan, Yahudi 


\section{Abstract}

Mamluks, reigned the near east area for 267 years (1250-1517), is one of the most significant states of Egypt and the history of the area in terms of establishment, organization and operation. In addition to being the longest-reigning monarch (1293-1341) in the history of Mamluks, Muhammed b. Kalavun is one of the significant monarchs with regard to his relations with Christian states of his time and non-Muslims in his state.

In this paper, it is aimed to study the religion factor having an impact on shaping Muhammed b. Kalavun Era socio-cultural and political history. It is beyond doubt that religion had a prominent role in internal and external politics in Mamluks, being a state attributing itself the role of patron of the Islamic World with its patronage of caliphate policy. Keeping the political clout, economic success and some exceptional cases apart, this era occupies and important place in terms of balanced politics in social structure. The aim of this study is to present the effect of religion, of which foundations was laid during the establishment period and was seen as a political motivation source, on state politics in Muhammed b. Kalavun Era.

Keywords: Mamluks, Muhammed b. Kalavun, Religion, Christian, Jewish

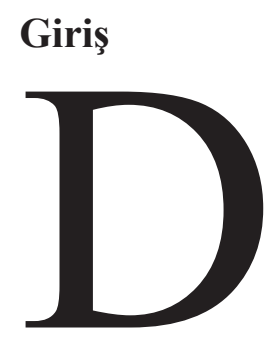

in, tanımı üzerinde ittifak sağlanamayan konulardan biridir. Farklı kaynaklar incelendiğinde, dinin yalnızca tanımı konusunda değil aynı zamanda içerik ve etkileri konusunda da farklı değerlendirmeler olduğu görülür. Din kavramını çeşitli boyutlarıyla ele alan bazı çalışmaların bu kavrama; rabıta, hürmet, gelenek ya da kulun yaratıcıya olan borcu şeklinde anlamlar verdikleri ${ }^{1}$ görülmektedir. Bu açıdan bakıldığında din çok boyutlu, kuşatıcı, hayatı yönlendirici bir özelliğe sahiptir. Eskiçağlardan günümüze kadar etki ve muhteviyat bakımından dinin bu özelliği zayıflamış görünse de hala önemlidir.

Memlûk Devleti kurulduğu sıralarda Haçlı Seferleri fiilî olarak etkisini yitirmiş ve seferler sırasında elde edilen kazanımlar korunmaya çalışılıyor olsa da fikrî açıdan haçlı düşüncesinin tamamen ortadan kalkmadığına ${ }^{2}$ hükmetmek için elde yeterince delil vardır. Hıristiyanlığın kadim geleneklerinin nüvesini teşkil eden üç merkezden ikisinin ${ }^{3}$ Muhammed b. Kalavun Dönemi'nde Memlûk hâkimiyet sahasına dâhil olduğu göz önünde bulundurulursa, dinin politik alana nüfuz

1 Din kavramının Yunanca, Latince, Arapça ve Farsçadaki terminolojik kullanımı ile ilgili olarak bk: Abdülhak Adnan Adıvar, Tarih Boyunca İlim ve Din (İstanbul: Türkiye İş Bankası Yayınları, 2012) 1: 2; Dinin toplumsal boyutları ile ilgili bir değerlendirme için bk: Ali Şeriatî, Dine Karşı Din çev. Hüseyin Hatemî (İstanbul: İşaret Yayınları, 1990), 73.

2 Haçlı Seferleri ve bazı dâhilî etkenlerin Endülüs’te ortaya çıkardığı Reconquista hareketinin İslam hâkimiyeti karşıtlığı üzerinden yeni bir bilinç oluşturduğu ve bunun da Muhammed b. Kalavun'un bu bölge devletleriyle ilişkilerini ister istemez etkilediği değerlendirilmektedir. Hıristiyanlık hassasiyetinin bu devletlerin oluşumundaki rolü hakkında bk: Evrim Türkçelik, "Muslim and Jewısh "Otherness" In The Spanish Natıon-Buıldıng Process Throughout The Reconquista (1212-1614)" (Yüksek Lisans Tezi, Ortadoğu Teknik Üniversitesi 2003), 27.

3 Hıristiyanlığın kadim merkezleri ile ilgili bir değerlendirme için bk: Ramazan Adıbelli, "Doğu Hıristiyanlarının Bugünkü Durumuna Genel Bir Bakış”, Milel ve Nihal 10, (2013): 13. 
eden dâhili ve haricî boyutlarını görmek mümkün olacaktır. Orta Çağ' da Roma dışında kalan iki önemli Hıristiyanlık merkezinin -İskenderiye ve Antakya Piskoposluğu- Memlûk nüfuz alanında olması Memlûkları sadece hilafeti himaye eden devlet olarak Müslümanların gözünde değil, Hıristiyanların gözünde de önemli bir devlet yapmaktaydı. Bu nedenle Hiristiyan devletlerin Memlûk Devleti ile olan münasebetlerinde dindaşları lehine bazı konularda müdahil oldukları görülmektedir.

Mısır'da Roma ve Bizans hâkimiyeti döneminde merkezî yönetimin tahkim etmek istediği ${ }^{4}$ resmî Hıristiyanlık ideolojisine karşı çıkan Hıristiyanlar gibi Yahudilerin de baskı altında kaldığı görülmektedir. Bu baskıların etkisiyle zamanla nüfusları azalmış olsa da Memlûk kaynaklarında Yahudilerle ilgili önemli bilgilere tesadüf edilmesi, bu cemaatin önceki dönemlerde olduğu gibi Muhammed b. Kalavun Dönemi’nde de varlığını sürdüren önemli dinî gruplardan biri olduğunu göstermektedir.

\section{1- Dış Politika Bakımından Ehl-i Zimmet ve Hıristiyan Dünya ile İlişkiler}

Muhammed b. Kalavun Dönemi'nde Memlûk hâkimiyeti altında yaşayan ehl-i zimmetin durumunu ortaya koyabilmek, adı geçen grubun gerek Müslüman toplum gerekse yönetici tabaka ile ilişkilerinin hangi zemine oturduğunu anlayabilmek için meselenin evveliyatını ortaya koymak gerekir. Zira olumlu ya da olumsuz her ilişki biçimini temellendirerek şekillendiren bir tarihî süreç vardir.

İnsanlığın genel gelişim çizgisi takip edildiğinde devletlerin/toplumların gerek kendi içindeki değişim ve dönüşümü gerekse başka devletler/toplumlarla olan münasebetinin günümüze yaklaştıkça birbirini etkileme hızı ve yoğunluğunun arttığı dikkatçekmektedir. Günümüz dünyasında küreselleşmenin etkisiyle bazı olguların ortadan kalktığı ya da önemini yitirerek detay olarak adlandırılabilecek küçük farklılıklara dönüştügü müşahede edilse de dinî farklılıkların hemen her yerde toplumsal hayatın önemli bir yönlendiricisi olduğu da bir gerçektir. Yakın zamanda ABD vatandaşı bir Müslüman'ın kendi kutsal kitabı üzerine yemin ederek göreve başlamas $1^{5}$ olumlu bir örnek teşkil ederken, Avrupa' da minare karşıtı eylemlerin ya da referandumların yapılması da ${ }^{6}$ aksi istikametteki bakış açılarının henüz müspet zemine ulaşamadığını ortaya koymaktadır.

İslâm dininin teorik boyutu yahut İslâm Devletlerinin başlangıçtan günümüze uzanan pratik uygulamaları tetkik edildiğinde görülecektir ki yöneticiler sınırsız yetkileri haiz kimseler değil, kendilerini bağlayan bazı usul ve esaslarla muamele etmek durumunda olan kişilerdir. Bu açıdan bakıldığında Orta Çağ’da hükümran olan bir İslâm Devleti'nin yöneticisi ile onun çağdaşı olan ve kendisini bir otoriteye hesap verme konumunun üstünde gören feodal sistemdeki herhangi bir Avrupalı yöneticinin konumları oldukça farklıdır. Makaleye konu olan Memlûk hükümdarı

4 Bilhassa Bizans Dönemi’ndeki baskılarla ilgili olarak bk: Georg Ostrogorsky, Bizans Devleti Tarihi, çev. Fikret Işı1tan (Ankara: Türk Tarih Kurumu Yayınları, 1995), 86-90; Bizans destekli Melekîler ile bu grubun muhalifi olan monofizit Kiptiler arasındaki çekişmeler hakkında bk: Aziz S. Atıya, Doğu Hıristiyanlı̆̆ Tarihi, çev. Nurettin Hiçyılmaz, (İstanbul: Doz Yayınları, 2005), 87-90.

5 ABD'de Emniyet Müdürlüğüne atanan ilk Türk olan İbrahim Mike Bayçora’nın Kuran-1 Kerim'e el basarak yemin etmesi hakkında bk: "Kuran’a El Basarak Yemin Etme Olayı" (erişim 5 Ağustos, 2020, www.hürriyet com.tr

629 Kasım 2009 tarihinde İsviçre'de yapılmış olan minare karşıtı referandum hakkında kaleme alınmış bir çalışma için bk: Murat Sadullah Çebi, "İsviçre'deki Minare Karşıtı Referandum Afişlerinde İslamofobi'nin Söylemsel İnşası”, Bilig, 73, (Bahar 2015): 99-140. 
Muhammed b. Kalavun, yalnızca Müslümanlarla ilgili olan hususlarda değil, ehl-i zimmet ile olan ilişkilerde de yüksek yargı mensuplarının görüşlerini almış, hatta bazı durumlarda onların muhalefetine rağmen bu zümre lehine ${ }^{7}$ kararlar almaktan geri durmamıştır.

Ehl-i zimmet başlı̆̆ı altında ele alınan Hıristiyanlar ve Yahudilerin Mısır, Suriye ve Lübnan'ın bazı bölgeleri başta olmak üzere Memlûk hâkimiyet sahasının doğal unsurları olarak hem toplum hem devlet nezdinde kabul gördügü müşahede edilmektedir. Bunun toplumsal yansıması Müslüman halkın bir bölümünün de Hıristiyanlarca kutsiyet atfedilen Nil kutlamalarına ${ }^{8}$ onlarla beraber katılmasıdır. Aynı şekilde yönetici kesim de ehl-i zimmete mensup bazı kişilere çeşitli tepkilere aldırış etmeden birtakım devlet görevlerini tevcih etmekten geri durmamışlardır. Günümüz dünyasında olduğu gibi Muhammed b. Kalavun Dönemi'nde de fanatik gruplar her iki kesimde de bazen seslerini yükseltmiş ve toplumsal ayrılığı körüklemenin yanında devlet mekanizmasının çalışma prensiplerini de zorlayacak eylemlerde bulunmuştur.

Mısır'da yaşayan Hıristiyanların çoğu Muhammed b. Kalavun döneminde Kıptî kökenli idi. Bu coğrafyanın kadim halkı olan Kıptîlerin tarihsel süreçte çeşitli milli ve dinî günler, anma ve kutlama etkinlikleri ihdas ettikleri9 ${ }^{9}$ örülmektedir. Bu dönemle ilgili bilgi veren kaynaklar Mısır Hıristiyanlarının kutladığı bayramlara bazen atıfta bulunan bazen de kutlama detaylarını tafsilatiyla anlatan kiymetli bilgiler vermektedir. Bu durum, incelenen dönemde söz konusu kutlamaların herhangi bir sosyal muhalefet yahut otorite baskısıyla engellenmediğini, bilakis bazen Müslümanların da iştirak etmesiyle ${ }^{10}$ toplumsal kaynaşmaya vesile olduğunu göstermektedir. Buna rağmen aşağıda görüleceği üzere bazı Avrupalı devletler, Muhammed b. Kalavun’a gönderdiği mektuplarda Memlûk hâkimiyet alanındaki Hıristiyanların dinî hürriyetlerinin temin edilmesi talebini dile getirmişlerdir.

Muhammed b. Kalavun Dönemi'nde Memlûk Devleti'nin Hıristiyanlarla ilişkilerini şekillendiren bazı haricî etkenler ${ }^{11}$ vardı. Bu etkenlerin başında, eski hâkimiyet alanındaki dindaşları

7 Muhammed b. Kalavun'un Divan-1 Mezalim oturumları düzenleme konusundaki hassasiyeti kaynaklarda yer bulan bir husustur. Bu mahkemelerin sultana her türlü sosyal sorunu ilk ağızdan dinleme ve daha sağlıklı kararlar alabilme şansı verdiği de açıktır. Memlûklarla ilgili eserinde J. D. Brandes'in; yangın, sel, deprem ve Nil taşkınları gibi her türlü musibetin kaynă̆ı olarak gayrimüslimleri gören fanatiklere karşı sultanın tavizsiz duruşunu takdir etmesi önemlidir. Konu hakkında bir değerlendirme için bk: JörgDieter Brandes, Die Mameluken. Aufstieg und Fall einer Sklavendynastie (Weisbaden 1996): 174

8 Abdulfettah Âşur, el-Müctemau'l-Mısri fi Asri Selatini'l-Memâlîk (Kahire: Dârü’n-Nehdati'l-Arabiyye 1992): 223; Mısır'ın hayat kaynağı olan Nil Nehri ile ilgili kutlama örnekleri için bk: Cüneyt Kanat, “Memlûk Devleti’nde Eğlence Kültürü”, Tarih İncelemeleri Dergisi XXII/1(2007): 57.

9 Kıptîlerin dinî inançları, günümüz Kıptî kilisesinin işleyişi, kullandıkları kendine özgü takvimleri, ayin ve ibadetleri hakkında temel bir bilgi için bk: Mustafa Erdem, "Monofizit Kiliselerinde Din Anlayışı (Kıptî Kilisesi Örneği)", Dinler Tarihi Araştırmaları II, (1998):92-96.

10 Makrizî, Kıptî Bayramları başlı̆̆ı altında Mısır Hıristiyanlarının bayramları hakkında bilgi vermektedir. Müellif konuya giriş yaparken İbn Abbas ve Hz. Ömer'e atfen Müslümanların bu bayramlara katılmaması yönündeki rivayeti daha ilk cümlede zikretmesine rağmen bu tavsiyenin Mısır'da bağlayıcı olmaması ilginçtir. Konuyla ilgili olarak bk: Ebü'l-Abbas Takıyyüddin Ahmed b. Ali b. Abdülkadir Makrizî, el-Mevaiz ve'l-İtibar bi Zikri'l-Hitat ve'l-Asâr el-Ma'ruf bi'l-Hitat-ı Makriziyye, (Beyrut:Darü's-Sadr, Tabatü Cedidetü Bil-Ufset, ts): 1:264.

11 Dinî aidiyetlerinden dolayı sıklıkla haricî müdahalelere maruz kalan Kisrevan (Lübnan) Bölgesi Hıristiyanları hakkında Muhammed b. Kalavun Dönemi Memlûk politikası ile ilgili olarak bk: Ebû Muhammed Bedreddin Mahmud b. Ahmed b. Musa el Aynî, Ikdü'l-Cûman fi Tarihi Ehli'z-Zaman: Asr Selâtin el-Memâlîk, neşr. Muhammed Muhammed Emin, (Kahire : el-Heyetü'l-Misriyyeti'l-Amme 
lehine birtakım taleplerde bulunan Bizans Devleti gelmekteydi. Dönemin kaynakları tetkik edildiğinde Muhammed b. Kalavun'un çağdaşı olan II. Andronikos'un ${ }^{12}$ Kudüs’teki bir kilisenin tekrar Hıristiyanlara iade edilmesi hususunda Memlûklara elçiler gönderdiği görülmektedir. ${ }^{13}$ Elçilik heyetlerinin ısrarla aynı istekte bulunmuş olması, Bizans Devleti'nin taleplerinin ilk anda karşılanmadığını ortaya koymaktadır. Ancak gerek dönemin doğrudan tanığı olan bazı tarihçilerin kayıtları ${ }^{14}$ gerekse birçok kaynağın taranmasıyla telif edilmiş tetkik eserler 1srarların sonuç verdiğini ve Muhammed b. Kalavun'un âlimlerin görüşünü aldıktan sonra kiliseyi eski sahiplerine iade ettiğini ${ }^{15}$ ortaya koymaktadır. Muhammed b. Kalavun'un Bizans taleplerini İslam âlimlerinden oluşan bir hakem heyetine götürmesi onun basireti hakkında da bir fikir verebilir. $\mathrm{Bu}$ tasarrufla sultanın meseleyi ilmî bir mecraya taşıyarak halkın muhtemel tepkilerini bertaraf ettiği, aynı zamanda Memlûklar açısından Bizans gibi önemli bir devlet ile olan ilişkilerinde de sorun alanlarından birini ortadan kaldırdığı değerlendirilebilir.

Muhammed b. Kalavun Dönemi’nde Haçl1ların elinde Memlûk nüfuz alanına giren üç bölge kaldığ 1 görülmektedir. Bunlar: Kilikya Ermenilerinin yaşadığ Çukurova bölgesi, Arvad adası ve Kıbrıs idi. Bilhassa Akka'nın fethinden sonra Papa IV. Nikola ${ }^{16}$ tarafından başlatılan ve çeşitli nedenlerle akamete uğrayan sefer planlarının hayata geçmediğ $i^{17}$ görülse de papalık kurumunun Hıristiyan dünyasındaki etkisinin siyasi alanla sınırlı kalmadığı hususu dikkatten kaçmamalıdır. Defalarca örneği görüldüğü gibi papaların ekonomik alanlara da nüfuz ederek Memlûklarla ticaret yapan devletler üzerinde baskı kurmak suretiyle ${ }^{18}$ Memlûk iktisadî hayatını olumsuz etkilemeye çalıştığı da bir gerçektir. Papalık müessesesi politikaları bir kenara bırakılacak olursa incelenen

li'l-Kitab, 1982) 4: 384, 385; Tarblus'un fethinden sonra Haçlılarla bağlantısı kesilen Kuzey Lübnan bölgesindeki Marunîlerin bir taraftan Haçlıların tekrar bölgeye gelmesini arzularken diğer taraftan Katolikleştirme faaliyetlerine maruz kalması ilginç bir çelişki olarak görülmektedir. Marunîlerin Katolikleştirilmesi için yapılan çalışmalar hakkında bk: Ramazan Işık, "Marunîleri Memlükler Döneminde Fransisken Misyoner Rahiplerin Katolikleştirme Faaliyetleri”, Cumhuriyet Üniversitesi İlahiyat Fakültesi Dergisi, IX/1: (2005), 203-218.

12 Bizans Devleti'ni 1282-1328 tarihleri arasında 46 yıl gibi uzun bir süre yönetmiş olan II. Andronikos dönemiyle ilgili bir değerlendirme için bk: Işın Demirkent, Bizans Tarihi Yazıları, (İstanbul: Dünya Kitaplar1, 2005), 116-117.

13 Dönemin doğrudan tanığı olan Baybars el-Mansûrî H. 710 (M. 1310/1311) olaylarını anlatırken elçilik heyeti ile ilgili olarak: "Sultana Rum tarafindan Kostantiniyye hâkimi Andronikos el-Eşkerî'nin aşağılanmaktan kurtulmak ve şefaat dilemek için gönderdiği elçiler geldi." ifadelerini kullanmaktadır. Konuyla ilgili olarak bk: Rükneddin Baybars el-Mansurî ed-Devâdar et-Tuhfetü'l-Mülûkiyye fi'dDevleti’t-Türkiyye, çev. Hüseyin Polat, (Ankara: Türk Tarih Kurumu Yayınları, 2016), 211.

14 Mufaddal b. Ebi'l-Fedail 718 yılı olaylarını anlatırken eski kiliselerin iadesinin ötesinde kilise imarından da bahsetmektedir. İlgili kayitlar hakkında bk: Samira Kortantamer, Agypten und Syrien zwischen 1317 und 1341 in der Chronik des Mufaddal b. Abi'i-Fadail, (Fereiburg: Klaus Schwarz Werlag, 1973), 451/5.

15 Mahmud Cemaleddin Surûr, Devletü Benî Kalavun fi Misr, (Kahire: Yayınevi yok, 1947), 260.

16 IV. Nikola 1288-1292 tarihler arasında bu makamda bulunmuştur. Bk: Walter Ullmann, A Short History of the Papacy in the Middle Ages (London: Methuen Co Ltd, 1972), 375. (Ayrıca Memlûk hükümdarları ile çağdaş olan Papalar ve Papalık tarihi hakkında aynı esere bakılabilir.)

17 Papalık tarafından organize edilmek istenen sefer planları hakkında bk: Muhammed Süheyl Takkuş, Tarihü'l-Memâlîk fi Mısr ve Bilâdi'ş-Şam 648-923 H/1250-1517 M., (Beyrut : Darü’n Nefâis, 1999), 233.

18 Papalık tarafından izlenen bu politikaların Muhammed b. Kalavun Dönemi'ndeki etki ve sonucu hakkında bir değerlendirme için bk: İlyas Gökhan-Ridvan Yiğit, "Muhammed b. Kalavun'un Üçüncü Saltanat Dönemi’nde (1310-1341/H. 709-741) Memlûk İktisadî Hayatını Etkileyen Unsurlara Genel Bir Bakış", Turkish Studies Historical Analysis 14/II (2019): 209. 
kaynaklar Aragon Devleti'nin Memlûk Devleti ile ilişkilerini iktisadî ve siyasi zeminden ziyade ağırlıklı olarak dinî zemine oturttuğu izlenimi vermekte, iki devlet arasında bazen diplomatik nezakete uygun bazen de tehditkâr ifadeler içeren mektuplaşmalar olduğu görülmektedir. Aragon Devleti tarafindan gönderilen elçilere verilen 15 Safer 723/ 23 Şubat 1323 tarihli cevabî mektupta Muhammed b. Kalavun, muhatap devletle iyi geçinmek istediklerini ancak İspanya'daki Müslümanların mescitlerinin kapanmasının, ezanlarının susmasının kendileri tarafından kabul edilemez olduğunu ${ }^{19}$ özellikle vurgulamaktaydı. Zira Humpreys tarafindan dikkat çekilen Memlûk tarihsel mirasının ${ }^{20}$ bu konuda onu harekete geçirecek derinlikte olduğunu göstermektedir.

Muhammed b. Kalavun ile çağdaş olan Fransa krallarının da dış politikada dini bir araç olarak kullandığg ve Memlûklarla ilişkilerinde bu hassasiyetin belirleyici olduğu görülmektedir. Öyle ki kaynaklarda Güzel Filip adıyla şöhret bulmuş olan IV. Filip iki papa öldürtmesinin yanı sıra -Papa V. Bonifas ve II. Benedikt- papalık merkezini de Avignon'a taşımıştı. ${ }^{21}$ Tıpkı selefleri gibi VI. Filip'in de bünyesinde önemli bir Hıristiyan kitle barındıran Memlûklarla ilişkilerinde özellikle Kudüs'ü gündeme getirerek Hıristiyanların hamisi rolünü üstlenmeye çalıştı̆̆ 1 , ancak Muhammed b. Kalavun'un Fransız elçilik heyetlerine itibar etmediği ${ }^{22}$ anlaşılmaktadır.

Muhammed b. Kalavun Dönemi'nde Avrupa merkezli Hıristiyan devletler ile Memlûk Devleti ilişkilerinin zemininin Habeşistan ile olan ilişkiden farklı olduğu görülmektedir. Buradaki Memlûk hâkimiyeti Zâhir Baybars Dönemi'nde tesis edilmişti ${ }^{23}$ ve Habeşistan Hıristiyanları dinî bakımdan Mısır Yakubî kilisesine bağlı idi. Bu nedenle iki devlet arasındaki ilişkilerde ister istemez din önemli bir rol oynamaktayd. Makaleye konu olan dönemde Habeşistan'1 yöneten Gabra Maskal'ın (1312-1344) Kahire'ye gönderdiği elçilerin talepleri ve mektuplarda kullanılan üslûp dikkate alındığında ${ }^{24}$ Memlûkların Habeşistan üzerinde ciddî bir yaptırım gücü olmadığı

19 Surûr, 271-272; Muhammed Mahmûd Neşşâr, Alâkatü Memleketi Kaştâle ve Arcûne bi-Saltanati'lMemâlikk (658-741/1260-1341), (Kahire: Ayn li'd-Dirasat ve'l-Buhusü'l-İnsaniyye ve'l-İ́ctimaiyye, 1997), 213. (Konuyla ilgili geniş bilgi için bilhassa Endülüs bölgesi devletleri ile Memlûklar arasındaki münasebetleri ortaya koymak için telif edilmiş olan bu esere bakılabilir.)

20 Humpreys tarafindan yapılan bir çözümleme, Memlûkların bölgede var olma mücadelesinde dinî hassasiyete asla sırt dönemeyeceğini veciz şekilde ortaya koymaktadır. Müellif, Sultan Baybars Dönemi'ni anlatan meşhur eseri yorumlarken: “íbn Abdizzahir'in Baybars hakkında yazdiğ $l$ resmî biyografiyi okuyan bir kimsenin, davul sesleri ve silahlar üzerine çarpan güneş ışıklarından dolayı başı ağrır." demektedir. Memlûkların cihat politikasını da içeren bir çalışma için bk: R. Stephen Humpreys, "XIII. Yüzyılda Eyyûbîler, Memlûkler ve Latin Doğu", çev. Mustafa Kılıç, Cumhuriyet Üniversitesi Illahiyat Fakültesi Dergisi, XI/I (2007): 359-378.

21 Papalık merkezinin Avignon'a taşınması, metinde bahsedilen papaların katli ve Güzel Filip ile Templer şövalyeleri arasındaki ilişkiler hakkında bk: Ronald Finucale, Huzursuzluk Dönemi, Hıristiyanlık Tarihi, çev. Sibel Sel-Levent Kınran (İstanbul: Us Yayınc1l1k, 2004), 334; Aytunç Altındal, Vatikan ve Tapınak Şövalyeleri (Ankara: Yeni Avrasya Yayınları, 2002), 52-53.

22 Surûr, 276-277.

23 İbn Şeddad, Baypars Tarihi (Al-Melik-Al-Zâhir (Baypars) Hakkındaki Tarihin İkinci Cildi), çev. Şerefüddin Yaltkaya (İstanbul: Maarif Matbaas1, 1941), 150.

24 Amda Sion'un (Gabra Maskal) Muhammed b. Kalavun'a yazdığı mektupta Mısır'daki kiliselerin tamir edilmesi, Hıristiyanlara emin bir şekilde hayatlarını idame ettirebilecekleri bir ortamın sağlanması gerektiği vurgulanıyordu. Üstelik bu uyarılar dikkate alınmazsa kendi ülkelerindeki Müslümanların zorluklar yaşayacağı hatta Nil nehrinin yatağının değiştirilerek Mısır'ın ölüme mahkûm edileceği söyleniyordu. Detaylar için bk: Surûr, 157,158; Bu dönemde İslam hâkimiyetinin bölgede zayıfladığı yönündeki bir değerlendirme için bk: DİA, Levent Öztürk (Ankara: Türkiye Diyanet Vakfı Yayınları, Cilt 11, 1995) "Etiyopya" maddesi. 
hükmüne varılabilir. Muhammed b. Kalavun'un, Habeş Müslümanlarından gelen ve orada temel hürriyetlerden mahrum bir şekilde yaşadıkları yönünde ifadeler içeren mektuplar nedeniyle patriği çağırarak ondan Gabra Maskal'a bir mektup yazmasını istediği ${ }^{25}$ bilinmektedir. Sultanın attığı bu adımla; mütekabiliyet ilkesini hatırlatmaya, kendi ülkesinde yaşayan Hıristiyanların dinî hürriyetlerden yararlanma ve devlet nezdinde temsil bakımlarından sorun yaşamadığını göstermeye çalıştı̆̆ı anlaşılmaktadır.

\section{2- İç Politika Bakımından Ehl-i Zimmet ve Hıristiyan Dünya ile İlişkiler}

Muhammed b. Kalavun'un, bir taraftan dış politikada dinî saiklerle hareket eden Hıristiyan devletlerle olan ilişkilerini sağlıklı bir şekilde idame ettirebilmek için uğraş verirken ${ }^{26}$ diğer taraftan kendi ülkesinde yaşayan Hıristiyan unsurla Müslüman halk arasında bir denge kurabilmek için gayret ettiği görülmektedir. Bu denge siyasetinin temel belirleyicileri arasında; Memlûk toplumunun dinî aidiyeti, farklı dinlere mensup grupların birbirine oranı, bu grupların sosyo-ekonomik hayatı yönlendirebilme kapasitesi, yönetici sınıfın din tercihleri, çeşitli devlet görevlerini hangi nedenlerle kimlere tevcih edeceklerine dair izledikleri politikalar sayılabilir.

Öncelikle Muhammed b. Kalavun Dönemi'nde demografik olarak Müslümanların ehl-i zimmete oranla mukayese edilemeyecek bir üstünlüğe sahip olduğunu tespit etmek gerekir. Ancak bu durum, ağırlıklı olarak Kıptîlerin oluşturduğu Hıristiyan unsur ya da kısmen Yahudilerin incelemeye konu olan dönemde herhangi bir etkinliği olmadığı anlamına gelmemektedir. Bilakis ciddi toplumsal tepkilere rağmen sultan tarafından bazı önemli makamlara ehl-i zimmete mensup kişilerin getirilmesi yönetim erkinin önceki İslam devletlerinde de örnekleri görüldüğü gibi tek ölçü olarak dinî aidiyeti görmediğini ortaya koymaktadır. Kaynaklar toplumsal muhalefetin ileri boyutlara ulaştığı dönemlerde yöneticilerin tepkileri hafifletmek amacıyla dönemsel bazı tedbirlere başvurmak zorunda kaldığı durumlardan da bahsetmektedir. Hac farizasını yerine getirmek üzere Fas'tan yola çıkarak Kalatü'l-Cebel'e uğrayan üst düzey bir grubun burada müşahede ettiği bazı durumların sultan nezdinde şikâyete konu olduğu görülmektedir. Çeşitli yüksek divan görevleri dâhil olmak üzere Memlûk Devletinde istihdam edilen Hiristiyan unsurdan haberdar olan grubun hayretler içerisinde kaldığı anlaşılmaktadır. Adı geçen grubun Muhammed b. Kalavun ile yaptığı toplantıda Hıristiyan ve Yahudilerden bazılarının da hazır bulunması, ${ }^{27}$ müzakere esnasında eşŞûrutü'l-Ömeriyye adıyla bilinen ve Hz. Ömer'in ehl-i zimmet ile yaptığı anlaşmanın² gündeme gelmesi ${ }^{29}$ önemlidir.

25 Konuyla ilgili mektup hakkında bk: Surûr, 157-158.

26 Muhammed b. Kalavun Dönemi’nde Hıristiyan devletlerle ilişkiler hakkında bir değerlendirme için bk: Ridvan Yiğit, "Muhammed b. Kalavun Dönemi’nde Misır'da Sosyal, Kültürel ve İktisadi Hayat", (Doktora Tezi, Nevşehir Hacı Bektaş Veli Üniversitesi, 2018), 119-130.

27 Surûr, 106.

28 Hz. Ömer ahitnamesinin içeriği, güvenirliliği ve hakkındaki tartışmalar ile ilgili olarak mukayeseli değerlendirmeler için bk: Corci Zeydan, İslam Medeniyeti Tarihi (İstanbul : Üçdal Neşriyat, 1966) 4: 165-182; DİA, Mustafa Fayda (Ankara: Türkiye Diyanet Vakfı Yayınları, 2010), "eş-Şürûtü’l-Ömeriyye” maddesi.

29 Sürecin ayrıntıları ile ilgili olarak dönemin doğrudan tanığı olan Nüveyri’nin kayıtları için bk: Ebü’l Abbas Şihabüddin Ahmed b. Abdülvehhab b. Muhammed el Bekrî et-Teymî el-Kureşî en-Nüveyrî, Nihayetü'l-Ereb fi Fünuni'l-Edeb (Kahire: Yayınevi yok, 1374) 31: 416-426. 
Memlûklar Dönemi'nde bazı olağanüstü şartların getirdiği uygulamalar hariçte tutulursa ehl-i zimmetin gündelik hayatta baskıdan uzak ve diledikleri gibi yaşama ortamına sahip oldukları görülmektedir. Örneğin Müslümanların da katıldı̆̆ 1 bir çeşit milli bayram olarak kabul gören Nevrûz, Kıptilerin kutladığı ve büyük merasimlere sahne olan önemli bayramlardan biriydi. Bunun dışında; Beşaret, Zeytûne, Fısıh, Hamis, Hamisü'l-Erbaîn, Milat ve Gıtâs bayramları kutlanmaktaydı Beşaret bayramı, Hz. Meryem'in Hz. İsa'ya hamile kalışının müjdelendiğine inanılması nedeniyle kutlanan bayramdır. Milat Hz. İsa’nın doğum günü, Zeytûne Kudüs’te Sion Dağı'da çıkışı, Fısıh çarmıha gerildikten sonra dirilerek havarileri ile son akşam yemeği yemesi nedeniyle kutlanırdı. Diğer önemli bayramlardan Hamisü'l-Erbaîn Hz. İsa'nın dirilmesinin üstünden geçen 40. günde Beyt Anyâ köyüne gitmesi, Hamis Sion dağında havarilerine tecelli etmesi ve Gıtâs bayramı da Hz. Yahya'nın Hz. İsa'yı vaftiz ettiğine inanılması nedeniyle ${ }^{30} \mathrm{~K} ı$ tî takvimine göre ${ }^{31}$ kutlanırdı.

Muhammed b. Kalavun Dönemi’nde Misırda yaşayan ehl-i zimmet Yahudi nüfusunu sağlıklı istatistiklere dayalı olarak ortaya koyabilecek herhangi bir kaynağa ulaşabilmiş değiliz. İlk İslâm fetihleri döneminde bölgenin cazibe merkezi olarak değerlendirebileceğimiz İskenderiye kentinde vergi ödeyen ve sayıları on binlerle ifade edilen bir Yahudi cemaatinden bahseden araştırmacılar olduğu gibi, bu sayının baskılar nedeniyle çok azaldığını ${ }^{32}$ ileri süren araştırmacılar da vardır.

Çeşitli kaynaklarda sayıları verilen ve izahı kabil olmayan farka rağmen istatistiklerin ortaya koyduğu bir gerçek varsa o da, Memlûkların devraldığı Mısır'da kendine özgü bir işleyişine sahip, dinî kimliğini koruyan bir Yahudi nüfusun varlığıdır. Bu yapının varlığına en büyük kanıt kaynaklarda şüpheye yer bırakmayacak açıklıkta vurgulandığı şekliyle Yahudi cemaatinin başında ibadet, vakıflar ve dinî yapılara müteallik çeşitli vazifeleri yürüten bir hahambaşı olduğunun ${ }^{33}$ ifade edilmesidir. Ancak bu cümleden Yahudi cemaatinin bir bütün olduğu ve tek bir makam tarafından temsil edildiği sonucuna varılmamalıdır. Zira Memlûk dönemi kaynaklarındaki bilgileri değerlendiren bazı çalışmalar bu cemaatin farklı mezheplere bölündüğü ve hahambaşının Rabbanî mezhebine mensup olanlardan seçildiğini ${ }^{34}$ ortaya koymaktadır.

30 Kutlama detaylarıyla ilgili olarak bk: Abdullah Sağır, İbn Tağriberdî’nin “el-Menhelü's-Sâf̂̂” Adlı Eserine Göre Kahire’de İlmî ve Sosyo-Kültürel Hayat, (Doktora Tezi, Marmara Üniversitesi, 2004), 336339.

31 Kronoloji tarih biliminin temelidir. Bu açıdan bakıldığında farklı takvim türleri ile kayıtlara geçen bazı bilgilerin günümüzdeki karşıllğıını ortaya koyma görevi yüklenen tarihçiler için tarih dönüştürme programları büyük ehemmiyet arz eder. Makrizî el-Hıtat adlı meşhur eserinde, güneş yılı esasına göre tanzim edilmiş olan Kıptî takviminin kamerî takvimde neye tekabül ettiğini açıklayarak kameri takvime geçişin tarihçesini vermiştir. Konuyla ilgili olarak bk: Makrizî, Hıtat, 1: 273 vd.

32 Aziz S. Atiya, S. L. Poole tarafından yapılan araştırma sonuçlarından hareketle 40.000'in üzerinde bir sayı verirken, Nuh Arslantaş 4.000 civarında bir nüfustan bahsetmektedir. Ayrıntılar ve mukayese için bk: Atiya,100; Nuh Arslantaş, Mısır'da Türkler, Araplar ve Yahudiler (İstanbul: İz Yayıncılık, 2015), 3637.

33 Memlûklar Dönemi sosyo-kültürel tarihine dair yazılmış meşhur eserlerden biri olan el-íntisar'da İbn Dokmak, Kahire'deki yapılardan bahsederken hahambaşı tarafından idare edilen Yahudi mabetleri hakkında da değerli bilgiler vermektedir. Ayrıntılar için bk: Sarimüddin İbrahim b. Muhammaed b. Aydemir İbn Dokmak, el-İntisar li Vasitati Akdi'l-Emsar fi Tarihi Mısr ve Cuğrafiyye ) Beyrut: Dârü'lAfâkı'l-Cedide, ts), 1: 32-41; Makrizî de Memlûklar Dönemi’nde aktif olarak kullanılmış Yahudi havralarının -Memlûk tarihçileri Kilise ve Havra ayrımı yapmadan her ikisine birden Kenise derler- (y.n) listesini verdikten sonra sayfalarca bu yapıların evsafını ortaya koymaktadır. Konuyla ilgili olarak bk: Makrizî, Hitat, 2: 464-472.

34 Rabbanî'ler dışında Mısır'daki diğer Yahudi mezhepleri Karraûn ve Samira’dır. Konuyla ilgili detaylı 
Dönemin kaynakları tetkik edildiğinde Memlûk sultanlarının bu tasarrufunda adı geçen mezhebe mensup olanların fazla olmasının dikkate alındığı yönündeki değerlendirme makul görünmektedir. Muhammed $b$. Kalavun'un genel siyaseti düşünüldüğünde çeşitli dinî ve sosyal gruplarla kendi liderleri vasıtasıyla iletişim kurduğu görülür. Bu siyasetin bazen bedevî şeyhleri aracılı̆̆ıyla bazen memlûk gruplarının büyükleri, bazen de dini cemaat önderleri üzerinden yürütülmeye çalışıldığı dikkat çekmektedir.

Mısır Yahudilerinin ibadethaneleri, tarihi ve bayramları üzerine müstakil bir başlık açan Makrizî’nin kayıtları, Muhammed b. Kalavun Dönemi'nde Mısır'da yaşayan Yahudi cemaatinin durumu hakkında genel bir çerçeve çizmeye yetecek bilgiler sunmaktadır. Eldeki veriler, Yahudilerin bu dönemde baskı altında kalmadan kendi milli ve dinî günlerini ve bayramlarını idrak edebilecek bir hürriyet ortamına sahip olduklarını göstermektedir. Mısır'da Memlûklar Dönemi'nde mevcudiyetini koruyan mezheplere göre farkl1lık gösteren bazı önemli günler olsa da her üç mezhebin müntesibi tarafından müşterek olarak kutlanan bayramlar arasında; Re'sü's-Sene, Kipûr, Mizalle, Fısıh ve Mevkıf bayramları vardı. Bunların dışında Fevz ve Hanuka/Heneke gibi millî bayram niteliği taşıyan özel günler Yahudiler tarafından kutlanırd..$^{35}$

Muhammed b. Kalavun Dönemi'nin doğrudan tanığı olan Nüveyrî tarafından aktarılan bazı bilgiler, ehl-i zimmetin devlet ile ilişkileri ve toplumsal statüleri konusunda yaşanan tartışmalara emirlerin de katıldığını ortaya koymaktadır. Müellifin kayıtlarına göre; gayrimüslimlerin silah taşımaması, Müslüman kıyafetlerine ${ }^{36}$ benzer kıyafet giymemeleri, kiliselerde casusluk faaliyeti yürütmemeleri, haç işareti taşımamaları, ölülerini Müslüman mezarlarına defnetmemeleri, evlerini Müslüman evlerinden yüksek inşa etmemeleri gibi hususlarda sultan da emirlerin taleplerine onay vermiştir. ${ }^{37}$

Güçlü toplumsal etkilere neden olabilecek bazı durumlara devletin geç müdahalesi yahut devlet erkinin aldığı kararların muhtemel sonuçlarının iyi tahlil edilememesi günümüzde de geçmişte de söz konusu olmuştur. Bu tarihî vakıanın konumuzla örtüşen bir örneğinin Muhammed b. Kalavun'un yukarıda açıklanmaya çalışılan kararlarından sonra gerçekleştĭgi görülmektedir. Alınan kararların İskenderiye'deki yansımaları değerlendirildiğinde iki kilisenin infiale kapılan Müslümanlar tarafından yıkıldığı sonucuna ulaşılabilir. Müslüman evlerinden yüksek olan bazı Hıristiyan evlerin de yıkıldığı yönündeki kayıtlar ${ }^{38}$, yaşanan hadiselerin Muhammed b. Kalavun'un

bilgi için Kâsım Abduh Kâsım, el-Yehud fî̀ Mısr (Kahire: Dârü'l-Fikr li'd-Dirasat, 1987), 31-34; Tarihsel pratik Mısır Yahudilerinin Re'sül-Câlut adını verdikleri cemaat liderlerini ve Yeşiva adını verdikleri cemaat meclislerini oluşturma konusunda serbest olduklarını göstermektedir. Konuyla ilgili olarak bk: Nuh Arslantaş, “Abbâsîler ve Fatımîler Dönemi’nde Yahudiler (132-656/750-1258)" , (Doktora Tezi, Marmara Üniversitesi, 2007), 66. (Bu durum aksi bir uygulamasını görmediğimiz Muhammed b. Kalavun Döneminde cemaatin haricî bir müdahaleye maruz kalmadan dinî cemaatini oluşturabildiğini ortaya koymaktadır.)

35 Mısır Yahudilerinin tarihi ve kutladığı bayramlarla ilgili genel bilgi için bk: Makrizî, Hıtat, 2: 472-480; Yahudi bayramları hakkında bilgi ve sosyo-kültürel değerlendirmesi için bk: Sağır, 339-344.

36 Memlûk Dönemi kıyafetleri konusunda bir eser yazan ve kadınların kıyafetlerini de ayrı bir başlık altında inceleyen bir eser için bk: Leo Aryah Mayer, Mamluk Costume (Geneve: Albert Kundıg, 1952), 69-74.

37 Nüveyrî, 31: 416 vd.

38 Ebü'l-Mehâsin Cemaleddin Yusuf b. Tagribirdî, en-Nücûmü'z-Zâhire fi Mülûk-ü Mısr ve'l-Kahire, thk. Muhammed Hüseyn Şemsuddin, (Beyrut: Darû'l-Kütübü'l-İlmiyye, 1423/ 1992) , 9: 55-60. 
emirlerle yaptığ 1 toplantı sonucunda ortaya çıkan kararların bir iz düşümü olduğu izlenimi vermektedir. Sultanın kendi tebaasının bir bölümünün mabetlerine karşı hücum edilmesinden son derece rahatsız olduğu, Müslim-gayrimüslim tüm unsurları içeren birtakım yeni düzenlemeler yapmak zorunda kaldığı ve yeni kiliseler inşa edilmesine onay verdiğine dair kayıtlar ${ }^{39}$ Muhammed b. Kalavun'un kendi ülkesinde dinî çatışmalara müsamaha göstermeme konusundaki kararlılı̆̆ını net olarak yansitmaktadir.

Muhammed b. Kalavun'un, ehl-i zimmet ile Müslüman toplum arasında cereyan eden bazı toplumsal krizlerin yönetiminde çok yönlü politikalar izlediği, halli zor meselelerde yalnız İslam âlimlerini değil Patriği de zaman zaman devreye soktuğ ${ }^{40}$ görülmektedir. Sultanın bu tasarrufu bazı bakımlardan önem arz etmektedir. Bu tutumun katılımcılığ 1 artırarak istenen sonucu almaya yardımc1 olduğu, toplum nezdinde manevî karşılığ1 olan dinî otoritelerin muhatap kitlelere ulaşmasıyla olayların daha kolay yatıştırıldığı müşahede edilmektedir. Ancak yalnız sultan değil, kadılar ve patriğin de devreye girdiği bazı durumlarda sükûnetin yine de sağlanamadığ́ anlaşılmaktadır. Bu durum, yerleşik bazı önyargıların kolay aşılamadığı, kökü derinlerde olan meselelerin iyi niyet ve katılımcılıkla da tam olarak çözülemediği ve sultanın dönemsel olarak görülebilecek sert tedbirlere başvurmak zorunda kaldığını göstermektedir. Çalışma konumuzla örtüşen bu neviden bir olay Tolunoğlu Ahmed Camii'ni ateşe verme teşebbüsüdür.

Nasıl ki küçük bir kıvılcım büyük bir yangın çıkarmaya yeterse, toplumsal olaylarda bazı söylentiler de tahminlerin çok ötesine geçen büyük olayların hazırlayıcısı olabilir. Kendinden önce yaşamış birçok tarihçinin kayıtlarından yararlanarak eserini telif eden İbn Tagribirdî tarafından verilen bilgiler, Hıristiyanlar tarafindan Tolunoğlu Ahmed Camii’nin yakıldığı söylentileri üzerine toplanan Müslüman halkın kısa sürede büyük bir gösterici gruba dönüştüğünü ortaya koymaktadır. Müslüman halkın nümayişi ve talepleri değerlendirildiğinde sultanı yalnızca Müslümanların başı olarak gördükleri ${ }^{41}$ hususu dikkat çekicidir. Kuşkusuz eldeki belgeler söz konusu protesto sırasında toplanan halkın ifadelerinin, Muhammed b. Kalavun Dönemi'nde Memlûk Devlet politikası olarak hâlihazırda var olan bir durumu göstermediği, daha çok bir temenni olabileceği izlenimi vermektedir. Ancak yine aynı kayıtlar Muhammed b. Kalavun gibi otoriter bir sultanın bile büyük kitlelerin baskısı karşısında bazen ehl-i zimmet hakkında hürriyeti tahdit izlenim veren kararlar ${ }^{42}$ almak zorunda kaldığını ortaya koymaktadır. Ancak müteakip süreçte dönemsel psikolojik durumun etkisiyle alınan bu kararların uygulanmadığı görülmektedir.

39 İbn Tagribirdî, en-Nücûm, 9: 55-60.

40 Detayları M.C. Surûr tarafından verilen kayıtlarda bazı Hıristiyanların ellerinde yanıcı maddelerle Müslüman mahallelerine gitmesi üzerine sultanın patriği çağırarak sert bir dille ondan olayları yatıştırmak için katkı sağlamasını istemiştir. Detaylar için bk: Surûr, 109.

41 Müellif, gösteriye katılan Müslümanların: "Sen bizim Nâsırımızsın” ifadeleriyle Muhammed b. Kalavun'un künyesine gönderme yaptığını (el-Melik en-Nâsır-Yardımcı) belirtmektedir. Konu ile ilgili olarak bk: İbn Tagribirdî, en-Nücûm, 9: 57.

42 Dönemin doğrudan tanığı olan Aybek ed-Devadâr'ın kayıtları tarandığında bu neviden birkaç kez sinırlama olduğu görülür. Bir örnek olarak Hicrî 700 yılında ehl-i zimmete uygulanan kıyafet kısıtlamasının nedenleri hakkında geniş malumat için bk: Ebûbekr b. Abdullah b. Aybek İbnü'd-Devadarî, Kenzü'd-Dürer ve Câmiu'l-Gurer: ed-Dürretü'z-Zekiyye fi Ahbâri Devleti (Mülüki)'t-Türkiyye, thk. Ulrıch Haarman, (Kahire: Yayınevi yok, 1971), 9: 47-50; Giyilecek kıyafetin evsafı ve bazı Hıristiyanların İslamiyet'i seçmesi hakkında bk: Ali Paşa Mübarek, el-Hıtatü't-Tevfikiyyetü'l-Cedide li Mısri'l-Kahire, 2. Basım, (Kahire: el-Hey'etül Mısriyyeti'l Âmme li'l Kitâb, 1980), 1: 98; Hıristiyanlara uygulanacak kuralların ayrıntısı için bk: Surûr, 110-111. 
Muhammed b. Kalavun Dönemi’nde ehl-i zimmet ile devlet ve Müslüman halkın ilişkileri değerlendirildiğinde tablonun yalnızca olumsuzluklardan oluşmadığı, günümüz dünyasında bile örnek gösterilebilecek beraberliklerin yaşandığı dikkat çekmektedir. Mısır'ın İslamî döneminden önce de Hıristiyan Kıptîler tarafından kutlandığı görülen Nevruz bayramına Müslümanların da iştirak etmesi ${ }^{43}$ dikkate değer bir husustur. Muhammed b. Kalavun Dönemi'nde vakıfların yönetimi ile ilgili olarak yapılan araştırmalar vakıf hizmetlerinden yalnızca Müslümanların değil, ehl-i zimmetin de istifade ettiğini göstermektedir. Hatta sultanın Hıristiyan ve Yahudilerin dinî ve sosyal örgütlenmesini engellemek şöyle dursun bu çabaları mersumlarıyla güvence altına aldığını ${ }^{44}$ ortaya koymaktadır. Memlûk vesikaları hakkında kaleme aldığı kıymetli esere binaen Memlûk diplomatikasının aşılmamış üstadı olarak görülen Kalkaşandî, Muhammed b. Kalavun Dönemi’ne ait olan bazı kıymetli evrakı doğrudan eserine almıştır. İlgili kayıtlara göre sultan Sina Dağı'ndaki ruhban sınıfından bahsederken; onların devletin ayrılmaz parçası olduğunu ve Müslümanlara da faydalarının dokunduğunu belirttikten sonra kendilerine her türlü kolaylığın sağlanmas ${ }^{45}$ emrini vermektedir. Makrizî tarafından verilen bilgiler de sultanın neden Sina ruhbanlarına karşı himayeci bir politika izlediği ile ilgili önemli ipuçları vermektedir. İlgili kayıtlar değerlendirildiğinde bazı hususlar dikkat çekmektedir. Bunlardan ilki sultanın: "Bizden öncekiler Sina ruhbanlarına iyi davrandı. Biz de öyle yapmalıyız." ifadelerini içermektedir ki bu durum Muhammed b. Kalavun öncesi Memlûk tarihinde -hatta çok daha önceki dönemlerde ${ }^{46}$ - ehl-i zimmete müsamahakâr bir yaklaşım olduğunu göstermektedir. Dikkat çeken ikinci husus urbanın (Bedevî Araplar) bölge Hıristiyanlarına zarar verme ihtimali ve üçünü husus Tur-u Sina bölgesi naiplerinin sultan emirlerini tavizsiz uygulamasi ${ }^{47}$ gerektiğidir.

\section{Sonuç}

Muhammed b. Kalavun Dönemi'nde devletin gayrimüslim unsurla ilişkileri bakımından dinin siyaseti önemli ölçüde etkilediği görülmektedir. Bu dönemde Haçlı Seferleri fiilî olarak

43 Memlûklar Dönemi'nde Mısır'ın oldukça canlı sosyo-kültürel hayatına dair örekler için bk: Ebü'l-Bereket Zeynüddin Muhammed b. Ahmed İbn İyas, Nüzhetü'l-Ümem fi'l-Acâib ve'l-Hikem, thk. Muhammed Zeynuhum Muhammed Azeb, (Kahire: Mektebetü Medbuli, 1995), 235-237; Nevruz bayramı ve kutlama merasimi hakkında bk: Mahmûd Rızk Selîm, Asru Selâtini'l-Memâlîk ve Nitâcühü'l-İlmî ve'l-Edebî (Kahire: Mektebetü'l Adab el-Cemami’ 1962), 2:355; Etkinliklerin iktisadi yönden değerlendirmesi için bk: Amir Necib Musa Nâsır, el-Hayatü'l-iktisadiyye fî̀ Mısr fî̀'l-Asri'l-Memluki (Amman: Dârü'ş-Şürûk, 2003), 342.

44 Hayat Nâsir el-Haccî, es-Sultanü'n-Nâsır Muhammed b. Kalavun ve Nizâmü'l-Vakf(Kuveyt: Mektebetü'lFelah, 1983), 78.

45 Mersumun tam metni için bk: Ebü’l Abbas Şihabüddin Ahmed b. Ali Kalkaşandî, Subhü’l-Â'şa fi Sinâati'l-İnşa, thk. Muhammed Hüseyin Şemseddin, (Beyru: Yayınevi yok, 1987), 11: 114.

46 Mısır'da hüküm süren bir başka Türk hükümdarı olan Tolunoğlu Ahmed'e, kendilerine karşı Müşvik yaklaşımından dolayı Yahudi ve Hıristiyan cemaatin dua ettiğine dair kayıtlar için bk: Ebu Ömer Muhammed b. Yusuf b. Yakub el-Kindî, Kitabü'l-Vulat ve Kitabü'l-Kudat, thk. Muhammed Hasan İsmail, Ahmed Feridî Mezidî , (Beyrut: Darü'l-Kütübü'l-İlmiyye, 2003), 231.

47 Ebü'l-Abbas Takıyyüddin Ahmed b. Ali b. Abdülkadir Makrizî, Kitâbü’s-Sülûk li-Ma'rifeti Düveli'lMülûk, neşr. Muhammed Mustafa Ziyade, (Kahire: Matbaatü'l-Cenne, 1939) 2/I: 232; 1310/h. 710 tarihli Moğoltay’a gönderilen bir mersumda Bedevilerin ruhbanlara zarar vermesi durumunda devletin derhal müdahale edeceği vurgulanmaktaydı. Mersumun içeriği ve değerlendirmesi hakkında ayrıca bk: elHaccî, Nizâmü'l-Vakf, 81. 
bitmişti. Ancak haçlıların Yakındoğu'da elde ettiği bazı önemli merkezler Memlûklar lehine el değiştirdiği için, incelenen dönemde Hıristiyan batı devletlerinin öncelikli hedefinin Memlûklar olduğu görülmektedir. Makalede açıklanmaya çalışılan Hıristiyanlığın üç kadim merkezinden ikisine bu dönemde doğrudan Memlûklar hükmediyordu. Bu durum dış politikada yalnız siyasi ya da iktisadi etkenlerin değil, aynı zamanda dinin Muhammed b. Kalavun ve onun çağdaşları tarafından politik bir unsur olarak neden kullanıldığını da ortaya koymaktadır.

Muhammed b. Kalavun Dönemi'nde Bizans Devleti'nin, ihtişamlı zamanları geride kalmış olmasına, içeride ve dişarıda çözülmesi güç sorunlarla uğraşmak zorunda kalmasına rağmen Kahire'ye gönderdiği elçilik heyetlerinin talepleri incelendiğinde Bizans'ın Misırda yaşayan Hıristiyanlar lehine düzenlemeler istediği görülmüştür. İstanbul'dan Kahire'ye gelen heyetlerin Memlûk hâkimiyet sahasındaki bazı kiliselerin imarı yahut tamiri hakkındaki talepleri tekrarlaması, ilk anda Muhammed b. Kalavun'un Bizans'a olumsuz cevap verdiğini ortaya koymaktadır. Ancak sultan tarafindan konunun bir âlimler heyetine havale edilmesi, İslam âlimlerinin olumlu görüş belirtmesi üzerine talep edilen kiliselerin sahiplerine iade edilmesi dikkat çekicidir.

Papalık kurumunun bu dönemde Avrupa’yı Memlûklara karşı fiili bir sefere teşvik edecek otoriteden uzak olduğu görülmüştür. Ancak sonuç vermemiş olsa da dönemin papalarının Memlûkları iktisadî alanda zora sokmaya yönelik bazı girişimlerde bulunduğu gerek ana kaynaklar gerekse tetkik eserlerde ortaya konan dikkate değer bir husustur. Bilhassa MemlûkAragon ilişkilerinde dinî hassasiyetlerin taraf devletlerin ilişkilerinde belirleyici bir rol oynadığ 1 görülmüştür. Reqonquista motivasyonu ile Endülüs'e hâkim olan Aragon'un Hıristiyanlık hassasiyeti taşıması gibi, Haremeyn'in ve Kudüs'ün hâkimi ve hâmisi olan Memlûkların da İslamî bir hassasiyet taşımasının doğal olduğu değerlendirilmektedir. Dönemin kaynakları Aragon elçilerinin Memlûk hâkimiyeti altında yaşayan Hıristiyanların mabetleriyle ilgili talepler gündeme getirdiğini ortaya koymaktadır. Buna karşılık Muhammed b. Kalavun’un mütekabiliyet anlayışıyla Endülüs Müslümanlarının ezanlarının susmasına olan tepkisini gündeme getiren mektuplarının, tezimizi doğrulayan belgeler olduğu düşünülmektedir. Fransız krallarının da Muhammed b. Kalavun'dan Kudüs özelinde bazı talepleri olduğuna yönelik elde kayıtlar mevcut ise de sultanın taleplere hüsn-ü kabul göstermediği net olarak görülmektedir. XIV. yüzyılın ikinci çeyreğinde Fransa'nın İngiltere ile girdiği büyük mücadele düşünüldügünnde bu devletin Memlûklara yaptırımda bulunacak güçten uzak olduğu hükmüne varmak mümkündür. Muhammed b. Kalavun Dönemi'nde Memlûkların, dinî farklılıklardan dolayı Habeşistan bölgesiyle büyük sorunlar yaşadığı da görülmüştür. Son söz olarak söylemek gerekirse; Muhammed b. Kalavun'un ehl-i zimmet politikası, içeride farklı din mensupları arasında ince bir denge kurma, dışarıda da İslamî hassasiyet ve himayeci yaklaşım düşüncesine dayanmaktaydi.

\section{Kaynakça}

Adıbelli, Ramazan. "Doğu Hıristiyanlarının Bugünkü Durumuna Genel Bir Bakış”, Milel ve Nihal 10 (2013):133-172.

Adıvar, Abdülhak Adnan. Tarih Boyunca İlim ve Din. İstanbul: Türkiye İş Bankası Yayınları, 2012.

Mübarek, Ali Paşa. el-Hitatü’t-Tevfikiyyetü'l-Cedide li Misri'l-Kahire. Kahire: el-Hey’etül Misriyyeti'1 Âmme li'1 Kitâb,1980. 
Altındal, Aytunç. Vatikan ve Tapınak Şövalyeleri. Ankara: Yeni Avrasya Yayınları, 2002.

Arslantaş, "Nuh. Abbâsîler ve Fatımîler Dönemi’nde Yahudiler (132-656/750-1258)." Doktora Tezi, Marmara Üniversitesi, 2007.

--------- Misır'da Türkler, Araplar ve Yahudiler. İstanbul: İz Yayıncılık, 2015.

Âşur, Abdulfettah. el-Müctemau'l-Mısri fi Asri Selatini'l-Memâlîk. Kahire: Dârü'nNehdati'l-Arabiyye, 1992.

Atıya, Aziz Suryal. Doğu Hıristiyanlığı Tarihi, çev. Nurettin Hiçyılmaz, İstanbul: Doz Yayınları, 2005.

Brandes, Jörg-Dieter. Die Mameluken: Aufstieg und Fall einer Sklavendynastie. Weisbaden, 1996.

Çebi, Murat Sadullah. “İsviçre'deki Minare Karşıtı Referandum Afişlerinde İslamofobi’nin Söylemsel İnşası.”, Bilig 73 (2015): 99-140.

Demirkent, Işıı. Bizans Tarihi Yazıları. İstanbul: Dünya Kitapları, 2005.

DİA. Levent Öztürk, 11. cilt Ankara: Türkiye Diyanet Vakfı Yayınları, 1995.

DİA. Mustafa Fayda, 39. cilt. Ankara: Türkiye Diyanet Vakfı Yayınları, 2010.

Ebûbekr b. Abdullah b. Aybek İbnü’d-Devadarî. Kenzü'd-Dürer ve Câmiu'l-Gurer: edDürretü'z-Zekiyye fi Ahbâri Devleti (Mülüki)'t -Türkiyye, thk. Ulrıch Haarman. Kahire: Yayınevi yok, 1971.

Ebû Muhammed Bedreddin Mahmud b. Ahmed b. Musa el Aynî. Ikdü'l-Cûman fi Tarihi Ehli'z-Zaman: Asr Selâtin el-Memâlîk, neşr. Muhammed Muhammed Emin. Kahire: el-Heyetü'lMisriyyeti'l-Amme li'l-Kitab, 1982.

Ebû Ömer Muhammed b. Yusuf b. Yakub el-Kindî. Kitabü'l-Vulat ve Kitabü'l-Kudat, thk. Muhammed Hasan İsmail, Ahmed Feridî Mezidî. Beyrut: Darü'l-Kütübü'l-İlmiyye, 2003.

Ebü'1 Abbas Şihabüddin Ahmed b. Abdülvehhab b. Muhammed el Bekrî et-Teymî el-Kureşî en-Nüveyrî. Nihayetü'l-Ereb fi Fünuni'l-Edeb. Kahire: Yayınevi yok, 1374.

Ebü'l Abbas Şihabüddin Ahmed b. Ali Kalkaşandî. Subhü'l-Â'şa fi Sınâati'l-İnşa, thk. Muhammed Hüseyin Şemseddin. Beyrut: Yayınevi yok, 1987.

Ebü'l-Abbas Takıyyüddin Ahmed b. Ali b. Abdülkadir Makrizî. el-Mevaiz ve'l-İtibar bi Zikri'l-Hitat ve'l-Asâr el-Ma'ruf bi'l-Hitat-1 Makriziyye. Beyrut: Darü's-Sadr, Tabatü Cedidetü Bil-Ufset, ts.

-Kitâbü's-Sülûk li-Ma'rifeti Düveli'l-Mülûk, neşr. Muhammed Mustafa Ziyade. Kahire: Matbaatü'l-Cenne, 1939.

Ebü'l-Bereket Zeynüddin Muhammed b. Ahmed İbn İyas. Nüzhetü'l-Ümem fi'l-Acâib ve'lHikem, thk. Muhammed Zeynuhum Muhammed Azeb. Kahire: Mektebetü Medbuli, 1995.

Ebü'l-Mehâsin Cemaleddin Yusuf b. Tagribirdî. en-Nücûmü’z-Zâhire fi Mülûk-ü Misr ve'lKahire, Cilt 9, thk. Muhammed Hüseyn Şemsuddin. Beyrut: Darû'l-Kütübü'l-İlmiyye, 1423/ 1992.

el-Haccî, Hayat Nâsır. es-Sultanü’n-Nâsır Muhammed b. Kalavun ve Nizâmü'l-Vakf. 
Kuveyt: Mektebetü'l-Felah, 1983.

Erdem, Mustafa. "Monofizit Kiliselerinde Din Anlayışı (Kıptî Kilisesi Örneği)", Dinler Tarihi Araştırmaları II, (1998): 89-97.

Finucale, Ronald. Huzursuzluk Dönemi Hıristiyanlık Tarihi, çev. Sibel Sel-Levent Kınran. İstanbul: Us Yayınc1l1k, 2004.

Gökhan İlyas -Ridvan Yiğit. “Muhammed b. Kalavun'un Üçüncü Saltanat Dönemi'nde (1310-1341/H. 709-741) Memlûk İktisadî Hayatını Etkileyen Unsurlara Genel Bir Bakış.”, Turkish Studies Historical Analysis 14/II (2019): 201-216.

R. Stephen Humpreys. "XIII. Yüzyılda Eyyûbîler, Memlûkler ve Latin Doğu.”, çev. Mustafa K1lıç, Cumhuriyet Üniversitesi İlahiyat Fakültesi Dergisi XI/1 (2007): 359-378.

Hürriyet. "Kuran'a El Basarak Yemin Etme Olayı” Erişim 5 Ağustos, 2020, www. http: // hürriyet.com.tr

Iş1k, Ramazan. "Marunîleri Memlükler Döneminde Fransisken Misyoner Rahiplerin Katolikleştirme Faaliyetleri.” Cumhuriyet Üniversitesi İlahiyat Fakültesi Dergisi IX/1 (2005): 203218.

İbn Şeddad. Baypars Tarihi (Al-Melik-Al-Zâhir (Baypars) Hakkındaki Tarihin İkinci Cildi), çev. Şerefüddin Yaltkaya. İstanbul: Maarif Matbaası, 1941.

Kanat, Cüneyt. "Memlûk Devleti'nde Eğlence Kültürü.” Tarih İncelemeleri Dergisi XXII/1 (2007): 53-62.

Kâsım, Abduh Kâsım. el-Yehud fî̀ Mısr. Kahire: Dârü'l-Fikr li’d-Dirasat, 1987.

Kortantamer, Samira. Agypten und Syrien zwischen 1317 und 1341 in der Chronik des Mufaddal b. Abi'i-Fadail. Fereiburg: Klaus Schwarz Werlag, 1973.

Mayer, Leo Aryah. Mamluk Costume. Geneve: Albert Kundig, 1952.

Musa Nâsır, Amir Necib. el-Hayatü'l-iktisadiyye fî̀ Misr fî̀'l-Asri'l-Memluki. Amman: Dârü'ş-Şürûk, 2003.

Neşşâr, Muhammed Mahmûd. Alâkatü Memleketi Kaştâle ve Arcûne bi-Saltanati'l-Memâlîk (658-741/1260-1341).Kahire: Ayn li'd-Dirasat ve'l-Buhusü'l-İnsaniyye ve'l-İctimaiyye, 1997.

Ostrogorsky, Georg. Bizans Devleti Tarihi, çev. Fikret Işıltan. Ankara: Türk Tarih Kurumu Yayınlar1, 1995.

Rükneddin Baybars el-Mansurî ed-Devâdar. et-Tuhfetü'l-Mülûkiyye fi'd-Devleti't-Türkiyye, çev. Hüseyin Polat. Ankara: Türk Tarih Kurumu Yayınları, 2016.

Sağır, Abdullah. “İbn Tağriberdî’nin ‘el-Menhelü’s-Sâfî’ Adlı Eserine Göre Kahire’de İlmî ve Sosyo-Kültürel Hayat.” Doktora Tezi, Marmara Üniversitesi, 2004.

Sarimüddin İbrahim b. Muhammaed b. Aydemir İbn Dokmak. el-İntisar li Vasıtati Akdi'lEmsar fi Tarihi Mısr ve Cuğrafiyye. Beyrut: Dârü'l-Afâkı'l-Cedide, ts.

Selîm, Mahmûd Rızk. Asru Selâtini'l-Memâlîk ve Nitâcühü'l-İlmî ve'l-Edebî. Kahire: Mektebetü'l Adab el-Cemami', 1962. 
Surûr, Mahmud Cemaleddin. Devletü Benî Kalavun fi Mısr. Kahire: Yayınevi yok, 1947.

Şeriatî, Ali. Dine Karşı Din. çev., Hüseyin Hatemî. İstanbul: İşaret Yayınları, 1990.

Takkuş, Muhammed Süheyl. Tarihü'l-Memâlîk fi Misr ve Bilâdi'ş-Şam 648-923 H/12501517 M. Beyrut: Darü’n Nefâis, 1999.

Türkçelik, Evrim. "Muslim and Jewısh 'Otherness' In The Spanish Natıon-Buıldıng Process Throughout The Reconquista (1212-1614).” Yüksek Lisans Tezi, Ortadoğu Teknik Üniversitesi, 2003.

Ullmann, Walter. A Short History of the Papacy in the Middle Ages. London: Methuen Co Ltd, 1972.

Yiğit, Ridvan. "Muhammed b. Kalavun Dönemi'nde Misır'da Sosyal, Kültürel ve İktisadi Hayat.” Doktora Tezi, Nevşehir Hacı Bektaş Veli Üniversitesi, 2018.

Zeydan, Corci. İslam Medeniyeti Tarihi. İstanbul: Üçdal Neşriyat, 1966. 